\title{
An annotated checklist of the insectivores (Mammalia, Lipotyphla) of Vietnam
}

\author{
Alexei V. Abramov, Dang Ngoc Can, Bui Tuan Hai \& Nguyen Truong Son \\ ABSTRACT. An annotated checklist of 32 extant species from 12 genera of the insectivores (Mammalia, \\ Lipotyphla) of Vietnam is provided. Many recently recorded/described species remain known from the \\ territory of Vietnam only: at least seven species of the white-toothed shrews (C. annamitensis, C. guy, $C$. \\ kegoensis, C. phuquocensis, C. sapaensis, C. sokolovi, C. zaitsevi) and a mole species (Euroscaptor \\ subanura).
}

KEY WORDS: mammals, Soricidae, Talpidae, Erinaceidae, checklist, distribution, systematics, Vietnam.

AlexeiV.Abramov [a.abramov@mail.ru], Zoological Institute, Russian Academy of Sciences, Universitetskaya nab. 1, Saint Petersburg 199034, Russia; Joint Vietnam-Russian Tropical Research and Technological Centre, Nguyen Van Huyen, Nghia Do, Cau Giay, Hanoi, Vietnam; Dang Ngoc Can [dncaniebr@yahoo.com.vn], Bui Tuan Hai [tuanhai.hus@gmail.com] and Nguyen Truong Son [soniebr@yahoo.com], Institute of Ecology and Biological Resources, Vietnam Academy of Sciences and Technology, 18 Hoang Quoc Viet Road, Hanoi, Vietnam.

\section{Аннотированный список насекомоядных млекопитающих (Mammalia, Lipotyphla) Вьетнама}

\author{
А.В. Абрамов, Д.Н. Кан, Б.Т. Хай, Н.Ч. Шон
}

РЕЗЮМЕ. Представлен аннотированный список насекомоядных млекопитающих (Mammalia, Lipotyphla) Вьетнама, включающий 32 современных вида из 12 родов. Многие виды известны только с территории Вьетнама - по меньшей мере, 7 видов землероек-белозубок (C. annamitensis, C. guy, C. kegoensis, C. phuquocensis, C. sapaensis, C. sokolovi, C. zaitsevi) и 1 вид кротов (Euroscaptor subanura).

КЛЮЧЕВЫЕ СЛОВА: млекопитающие, Soricidae, Talpidae, Erinaceidae, чеклист, распространение, систематика, Вьетнам.

Vietnam occupies the key geographic position within Southeast Asia and holds a diverse mammal fauna (Sterling et al., 2006). During the last two decades intensive zoological surveys have resulted in the discovery of new distributional records and description of several new species from Southeast Asia, particularly from Vietnam. According to the latest comprehensive checklist by Dang Ngoc Can et al. (2008), the mammal fauna of Vietnam consists of 295 species, including 22 species of insectivorous mammals (Lipotyphla). Many new data on small mammals that have appeared since 2008 indicate that the current knowledge of richness and distribution of Vietnamese lipotyphlan species are still incomplete (Bui Tuan Hai et al., 2013a).

In the present paper, an annotated and updated checklist of the insectivorous mammals (Mammalia, Lipotyphla) of Vietnam, as compared to that of Dang Ngoc Can et al. (2008), is provided. New revisions and records of Vietnamese lipotyphlan taxa produced during the last decade justify the compilation of a new species list for the country. We have provided additional references on distribution, taxonomy and other relevant aspects in the "Comments" section provided for each species. The following checklist is relied upon an extensive literature review and the analysis of available museum specimens from the collections of the Zoological Institute, Russian Academy of Sciences, Saint Petersburg, Russia (ZIN), the Zoological Museum, Moscow State University, Moscow, Russia (ZMMU), and the Institute of Ecology and Biological Resources, Vietnam Academy of Sciences and Technology, Hanoi, Vietnam (IEBR). The high-level taxonomic nomenclature follows Bannikova \& Lebedev (2012), who consider Erinaceomorpha, Soricomorpha and Talpomorpha as suborders of the order Lipotyphla (Eulipotyphla sensu Bannikova \& Lebedev, 2012). 1910

SUBORDER ERINACEOMORPHA Gregory,

Family ERINACEIDAE G. Fischer, 1814

Subfamily Galericinae Pomel, 1848

Neotetracus sinensis Trouessart, 1909

Type locality. China, Sichuan Province, Ta-tsienlou, elevation $2454 \mathrm{~m}$ a.s.l. 


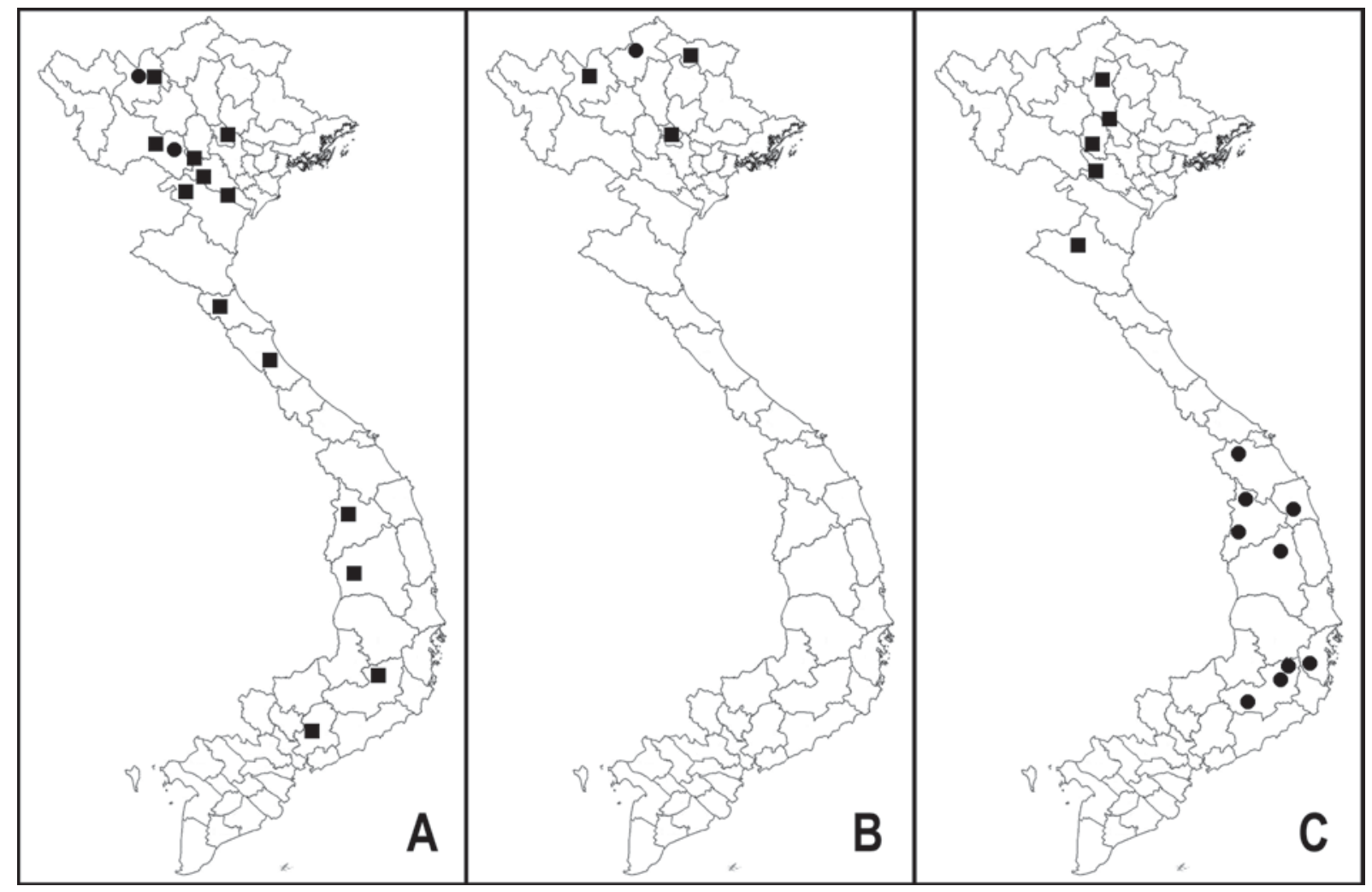

Figure 1. Distribution maps of the Vietnamese insectivores: A - Neotetracus sinensis (circles), Hylomys suillus (squares); B - Scaptonyx fusicaudus (circles), Euroscaptor longirostris (squares); C - Euroscaptor parvidens (circles), Euroscaptor subanura (squares).

Distribution. Southern China (Sichuan, Yunnan, Guizhou), northern Myanmar and northern Vietnam (Hutterer, 2005; Hoffmann \& Lunde, 2008).

Distribution in Vietnam. Northern Vietnam (Fig. 1A), collected from Sa Pa District, Lao Cai Province (Kuznetsov \& Rozhnov, 1998; Abramov et al., 2008), and Muong Do Nature Reserve, Son La Province (Nguyen Xuan Dang et al., 2012).

Hylomys suillus Müller, 1840

Type locality. Indonesia, "Java en het andere van Sumatra" ("Mt. Gede, western Java" according to Corbet \& Hill, 1992: 24).

Distribution. Throughout Indochina from southern China (Yunnan) and northern Myanmar to Peninsular Malaysia, islands of Borneo, Java, Sumatra and Tioman (Hutterer, 2005).

Distribution in Vietnam. Northern, central and southern Vietnam (Fig. 1A). There are museum specimens (ZIN, IEBR and ZMMU collections) from Son La Province (Ta Xua Nature Reserve, Phu Yen District), Vinh Phuc Province (Tam Dao), Ha Noi Area (Ba Vi National Park), Hoa Binh Province (Kim Boi District), Ha Tinh Province (Vu Quang Nature Reserve), Quang Binh Province (Le Thuy District), Gia Lai Province (An Khe District), Lam Dong Province (Cong Troi pass), Dong Nai Province (Ma Da Forest, Vinh Cuu Nature Reserve). The species has also been recorded from Lao Cai Province (Bao Ha and Thai Nien), Kon Tum Province (Dak To) (Thomas, 1925, 1927; Osgood, 1932), Thanh Hoa Province (Lang Chanh District) (Dao Van Tien, 1966; Cao Van Sung, 1976) and Ninh Binh Province (Cuc Phuong National Park) (Feiler et al., 2008).

\section{SUBORDER TALPOMORPHA Bugge, 1974}

Family TALPIDAE G. Fischer, 1814

\section{Subfamily Talpinae G. Fischer, 1814}

Tribe Scaptonychini Van Valen, 1967

Scaptonyx fusicaudus Milne-Edwards, 1872

Type locality. China, Qinghai Province, "frontière du Kokonoor” (= vicinity of Kukunor, or Qinghai, Lake).

Distribution. Northern Myanmar, central and southern China (Qinghai, Shensi, Sichuan and Yunnan), northern Vietnam (Hutterer, 2005).

Distribution in Vietnam. Northern Vietnam (Fig. 1B), with the only record from the vicinity of Mt. Tay Con Linh II, Ha Giang Province (Lunde et al., 2003). 
Comments. The specimen from Mt. Tay Con Linh II represents the only record of $S$. fusicaudus from Vietnam. This specimen is similar to $S$. fusicaudus affinis in having the third lower premolar being only slightly larger than the second one. However, the number of specimens available to us is not enough to adequately assess the taxonomic significance of this similarity (see Lunde et al., 2003).

Tribe Talpini G. Fischer, 1814

Euroscaptor* longirostris (Milne-Edwards, 1870)

Type locality. China, Sichuan Province, Moupin (=Baoxing).

Distribution. Southern China (Hutterer, 2005; Hoffmann \& Lunde, 2008), northern Vietnam.

Distribution in Vietnam. Northern Vietnam (Fig. 1B). It has been recorded from $\mathrm{Sa} \mathrm{Pa}$ District, Lao Cai Province (Osgood, 1932; Abramov et al., 2008; Kawada et al., 2009), from the vicinity of Tam Dao Town, Vinh Phuc Province (Kawada et al., 2008; 2009), and from Nguyen Binh District, Cao Bang Province (Kawada et al., 2009).

Comments. The specimens of E. longirostris from NW and NE Vietnam are morphologically variable, particularly in their fur density, coloration, tail shape and length (Kawada et al., 2009).

\section{Euroscaptor parvidens (Miller, 1940)}

Type locality. Vietnam, Lam Dong Province, agricultural station of Blao, "Délégation de Djynrinh" (= Di Linh), near the upper Dong Nai River, Lam Dong Province, elevation $800 \mathrm{~m}$ a.s.l.

Distribution. Southern Yunnan, China (Wang, 2003; Hoffmann \& Lunde, 2008) and Vietnam.

Distribution in Vietnam. Southern and central Vietnam (Fig. 1C). The species has been recorded from few localities in Dalat Plateau, southern Vietnam. The type specimen came from Di Linh District, Lam Dong Province (Miller, 1940). Few specimens were collected from Chu Yang Sin National Park, Dak Lak Province (Dang Ngoc Can et al., 2008; Kawada et al., 2009) and the Bi Doup - Nui Ba National Park, Lam Dong Province (Abramov et al., 2010a). There are museum specimens collected from Hon Ba Mt., Khanh Hoa Province (IEBR collection), Bao Lam District and the vicinity of Dalat, Lam Dong Province (IEBR, ZIN and ZMMU collections). Another isolated distribution area exists in central Vietnam. The moles have been found from Ngoc

* On the basis of morphological data (Motokawa, 2004) and analysis of mitochondrial and nuclear genes (Zemlemerova et al. 2013), the genus Euroscaptor was found to be a paraphyletic taxon Taking into account the phylogenetic position of Scaptochirus Milne-Edwards, 1867 within the radiation of Euroscaptor Miller, 1940 , the former can probably be combined with the second one and retain the generic name Scaptochirus as its senior synonym (see Zemlemerova et al., 2013). Further analysis of an extended set of nuclear loci is required to resolve this taxonomic problem.
Linh Mt., Kon Tum Province (Abramov et al., 2007a) and Dong Giang District, Quang Nam Province (Dang Ngoc Can et al., 2008; Kawada et al., 2008, 2009). Recently the species has been recorded from Kon Ka Kinh National Park, Kon Tum Province, Chu Mom Ray National Park, Gia Lai Province, and Ba To, Quang Ngai Province (Dang Ngoc Can et al., 2013, in press; IEBR collection). There are unconfirmed records from Cat Tien National Park, situated in Dong Nai Province southward of Dalat Plateau (Pham Nhat et al., 2001).

Comments. Some authors listed the northern Vietnam in the distribution range of E. parvidens (Stroganov, 1948; Pavlinov, 2003; Hutterer, 2005; Chiozza, 2008; Hoffmann \& Lunde, 2008). This erroneous opinion was based on the paper by Miller (1940) who had mentioned the record of E. parvidens from "Pakho on the frontier of China". This record is most likely to be attributed to E. longirostris or Mogera latouchei. Although Wang (2003) mentioned E. parvidens as being distributed in Jinping, southern Yunnan, China, the morphological characters of the Chinese specimens need to be examined in detail (Kawada et al., 2009).

Euroscaptor subanura Kawada, Nguyen Truong Son, Dang Ngoc Can, 2012

Type locality. Vietnam, the northwestern slope of Tam Dao Mountain, near Vuoc Ly Village, Hiep Hoa Commune, Son Duong District, Tuyen Quang Province, elevation $250 \mathrm{~m}$ a.s.1.

Distribution. Known from Vietnam only.

Distribution in Vietnam. Northern Vietnam (Fig. 1C). It has been found in the northwestern low-elevation slope of Tam Dao Mt., Tuyen Quang Province. This species has also been recorded from $\mathrm{Na}$ Hang Nature Reserve, Tuyen Quang Province, and Pu Huong Nature Reserve, Nghe An Province (Kawada et al., 2012). Recently the species has been found in Xuan Son National Park, Phu Tho Province (Shinohara et al., 2013; IEBR and ZIN collections) and Ba Vi National Park, Ba Vi“" District of Hanoi (Abramov et al., 2013).

Comments. The known distribution of this species is scattered around northern Vietnam. All the localities lie in relatively low mountains surrounded by plain areas. In its type locality (Tam Dao), this species is known from 200 to $300 \mathrm{~m}$ a.s.1., while another species E. longirostris occurs at a higher elevation (about 1000 $\mathrm{m}$ a.s.1.). The higher habitat of moles in Tam Dao area includes farms and townships, but there are no records of E. subanura from such habitats. Therefore it is safe to conclude that E. subanura is adapted to the lowland forests of northern Vietnam (Kawada et al., 2012).

Mogera latouchei Thomas, 1907

Type locality. China, north-west of Fujien Province, elevation 3500 feet $(1067 \mathrm{~m})$ a.s.l.

Distribution. Southern China (Hoffmann \& Lunde, 2008), northern Vietnam (Kawada et al., 2009). 


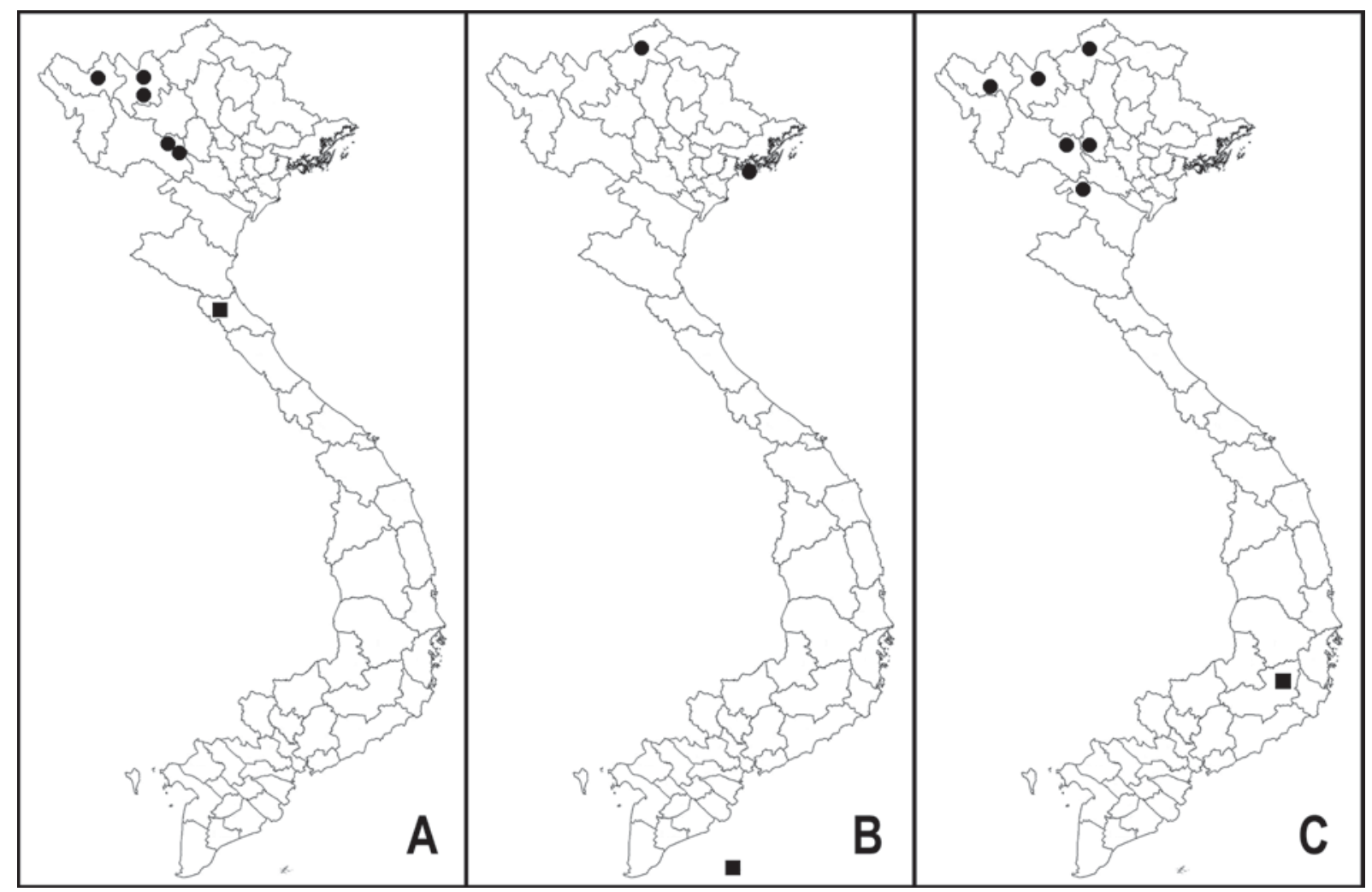

Figure 2. Distribution maps of the Vietnamese insectivores: A - Mogera latouchei (circles), Crocidura annamitensis (squares); B - Crocidura attenuata (circles), Crocidura fuliginosa (squares); C - Crocidura dracula (circles); Crocidura indochinensis (squares).

Distribution in Vietnam. Northern Vietnam (Fig. 2A). It has been found in few localities of Lao Cai Province: Nam Xay Commune, Van Ban District (Abramov et al., 2009) and near Sa Pa Town (Kawada et al., 2009). Few specimens have been collected from Sin Ho District, Lai Chau Province (IEBR collection); Phu Yen District, Son La Province (ZIN and IEBR collections); Nguyen Binh District, Cao Bang Province (Kawada et al., 2009) and Muong Do Nature Reserve, Son La Province (Nguyen Xuan Dang et al., 2012).

Comments. This species was long considered a subspecies of $M$. insularis from Taiwan, but recently has been accepted as a full species. M. latouchei is often found in farmlands that therefore are considered a good habitat for this species (see Kawada et al., 2009).

\section{SUBORDER SORICOMORPHA Gregory, 1910}

\section{Family SORICIDAE G. Fischer, 1814}

\section{Subfamily Crocidurinae Milne-Edwards, 1872}

Crocidura annamitensis Jenkins, Lunde, Moncrieff, 2009

Type locality. Vietnam, Ha Tinh Province, Huong Son District, Huong Son Camp, elevation 920 m a.s.l.

Distribution. Known from Vietnam only.
Distribution in Vietnam. Central Vietnam (Fig. 2A). Known from the type locality in Huong Son District, Ha Tinh Province only (Jenkins et al., 2009).

Crocidura attenuata Milne-Edwards, 1872

Type locality. China, Sichuan Province, Moupin (= Baoxing).

Distribution. India (Assam, Sikkim), Nepal, Bhutan, Myanmar, Thailand, Vietnam, southern China (from eastern Xizang to Hainan and northern to southern Gansu), northern Laos (Hutterer, 2005; Jenkins et al., 2009). The occurrence in Peninsular Malaysia seems to be doubtful (see Hutterer, 2005).

Distribution in Vietnam. The northeastern territory of Vietnam (Fig. 2B), to the north and east of the Red River (see Bannikova et al., 2011). The confirmed records are known from Mt. Tay Con Linh II in Ha Giang Province (Esselstyn \& Oliveros, 2010; Bannikova et al., 2011) and Cat Ba Island, Hai Phong Province (Abramov et al., 2012; Abramov \& Kruskop, 2012).

Comments. Most authors (Heaney \& Timm, 1983; Dang Huy Huynh et al., 1994; Hutterer, 2005; Kuznetsov, 2006; Dang Ngoc Can et al., 2008; Jenkins et al., 2009) suggested a wide geographic distribution for $C$. attenuata in Vietnam. However, the recent study of mitochondrial DNA (Bannikova et al., 2011) restricted 
its distribution only to the northernmost part of Vietnam. Elsewhere in the mainland Vietnam it is replaced by $C$. tanakae.

\section{Crocidura dracula Thomas, 1912}

Type locality. China, Yunnan Province, "probably near Mong-tze".

Distribution. Southern China, northern India, Myanmar, northern Vietnam.

Distribution. Northern Vietnam (Fig. 2C). Osgood (1932) listed the specimens from Ngai Tio and $\mathrm{Sa} \mathrm{Pa,}$ Lao Cai Province, Muong Mo and Lai Chau, Lai Chau Province and Hoi Xuan, Thanh Hoa Province. There is genetically confirmed record from Mt. Tay Con Linh II, Ha Giang Province (as C. fuliginosa in Lunde et al., 2003; species identification by Bannikova et al., 2011). Recently the species was recorded from Phu Yen District, Son La Provinces (IEBR and ZIN collections) and Xuan Son National Park, Phu Tho Province (IEBR collection).

Comments. Many papers listed $C$. fuliginosa as being widespread in the mainland Vietnam (Heaney \& Timm, 1983; Dang Huy Huynh et al., 1994; Kuznetsov, 2006; Dang Ngoc Can et al., 2008; Jenkins et al., 2009). However, recent comparative studies of mitochondrial DNA (Bannikova et al., 2011; Abramov et al., 2012) did not confirm its occurrence there. Bannikova et al. (2011) proposed to re-establish the name $C$. dracula for the large white-toothed shrews from northern Vietnam and southern China.

Crocidura fuliginosa (Blyth, 1855)

Type locality. Myanmar, Schwegyin, near Pegu (= Bago).

Distribution. Malay Peninsula and adjacent islands, Myanmar, Vietnam.

Distribution in Vietnam. Southern Vietnam (Fig. 2B). The species' occurrence has only been confirmed for Con Son and Bai Canh islands of Con Dao Archipelago, Ba Ria - Vung Tau Province (Van Peenen et al., 1970; Abramov et al., 2012).

Comments. The occurrence of $C$. fuliginosa in the mainland Vietnam is still questionable (see Abramov et al., 2012). Jenkins et al. (2009) provided two records based on survey reports rather than on museum voucher specimens. One of them (Le Trong Trai et al., 1999), reporting $C$. fuliginosa from Ngoc Linh Mt. in Kon Tum Province, was based on a visual observation only. Another location mentioned was Nui Bi Doup, Lam Dong Province (Jenkins et al., 2009). None of these locations are confirmed by voucher specimens (see Abramov et al., 2012).

Crocidura fuliginosa was described from central Myanmar (Blyth, 1855), so biogeographically it is unclear whether this name can be applied to the Vietnamese taxon. The DNA-confirmed records of Vietnamese haplogroup are known from Cameron Highland, Peninsular Malaysia (see Bannikova et al., 2011).
Crocidura guy Jenkins, Lunde, Moncrieff, 2009

Type locality. Vietnam, Tuyen Quang Province, Na Hang Nature Reserve, Tat Ke Sector, elevation 300-800 m a.s.l.

Distribution. Known from Vietnam only.

Distribution. Northern Vietnam (Fig. 3A). Known from the type locality in Tuyen Quang Province only (Jenkins et al., 2009).

\section{Crocidura indochinensis Robinson, Kloss, 1922}

Type locality. Vietnam, Lam Dong Province, Dalat, Langbian Plateau, elevation 5000 feet (1524 m) a.s.l.

Distribution. Myanmar, northern Thailand, southern China (Yunnan, Fujian, Sichuan), Vietnam (Hutterer, 2005; Hoffmann \& Lunde, 2008). The exact distributional limits remain unknown. According to Jenkins et al. (2009), this species seems to have a disjunct range, being found in China (Yunnan), Myanmar (Kachin) and Vietnam.

Distribution in Vietnam. Southern Vietnam (Fig. 2C). It has been found in a couple of localities in Dalat Plateau, Lam Dong Province: near Dalat (Robinson \& Kloss, 1922; Jenkins et al., 2013) and $5 \mathrm{~km} \mathrm{NE}$ of Long Lanh Village, Bi Doup - Nui Ba National Park (Abramov et al., 2010a).

Comments. Bannikova et al. (2011) did not find any members of the $C$. indochinensis haplogroup in northern Vietnam and southern China. Specimens from $\mathrm{Sa} \mathrm{Pa}$ District, Lao Cai Province, previously referred to as $C$. indochinensis (Jenkins et al., 2009), have been recently re-identified as $C$. sapaensis (see Jenkins et al., 2013).

Crocidura kegoensis Lunde, Musser, Ziegler, 2004

Type locality. Vietnam, Ha Tinh Province, "Ky Anh - Ke Go" (= "Ke Go" or "Ho Ke Go") Nature Reserve, elevation about $200 \mathrm{~m}$ a.s.l.

Distribution. Known from Vietnam only.

Distribution in Vietnam. Central Vietnam (Fig. 3A). Known from the type locality in Ha Tinh Province only (Lunde et al., 2004; Jenkins et al., 2009).

Crocidura phanluongi Jenkins, Abramov, Rozhnov, Olsson, 2010

Type locality. Vietnam, Dak Lak Province, northern portion of Yok Don National Park, elevation 250 $\mathrm{m}$ a.s.l.

Distribution. Southern Vietnam, northeastern Cambodia.

Distribution in Vietnam. Southern Vietnam (Fig. 3B). It has been found in Yok Don National Park in Dak Lak Province; Ma Da Forest, Vinh Cuu Nature Reserve in Dong Nai Province; Binh Chau - Phuoc Buu Nature Reserve in Ba Ria - Vung Tau Province (Jenkins et al., 2010); Bu Gia Map Nature Reserve in Binh Phuoc Province (Abramov et al., 2011; Bannikova et al., 2011), 


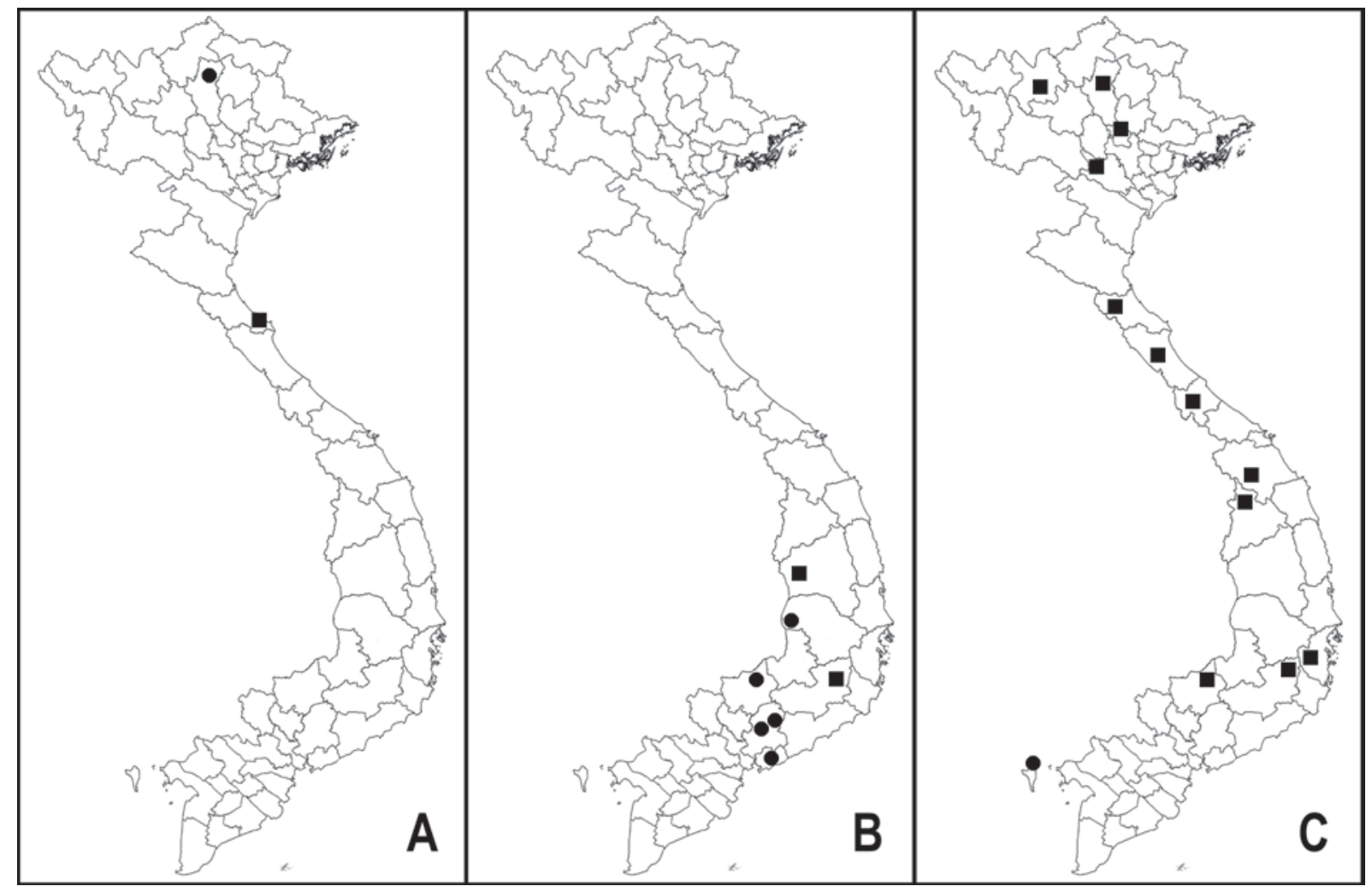

Figure 3. Distribution maps of the Vietnamese insectivores: A - Crocidura guy (circles), Crocidura kegoensis (squares); $\mathrm{B}$ - Crocidura phanluongi (circles), Crocidura rapax (squares); C - Crocidura phuquocensis (circles), Crocidura tanakae (squares).

and Cat Tien National Park in Dong Nai Province (ZIN collection, ZMMU collection).

Comments. The specimen from Binh Chau - Phuoc Buu Nature Reserve in Ba Ria - Vung Tau Province, referred to by Jenkins et al. (2010) as C. phanluongi, may represent a distinct species (see Bannikova et al., 2011).

Crocidura phuquocensis Abramov, Jenkins, Rozhnov, Kalinin, 2008

Type locality. Vietnam, Kien Giang Province, northern part of Phu Quoc Island, c. $5 \mathrm{~km}$ west of Bai Thom Village, elevation $30 \mathrm{~m}$ a.s.1.

Distribution. Known from Vietnam only.

Distribution in Vietnam. Southern Vietnam (Fig. 3C). Known only from the type locality in Phu Quoc Island (Abramov et al., 2008, 2012).

\section{Crocidura rapax G. Allen, 1923}

Type locality. China, south of Yunnan Province, Mekong River, Ying-pan-kai, elevation 9000 feet (2745 m) a.s.l.

Distribution. Reported from northeastern India, northern Myanmar, throughout southern China (Sichuan, Yunnan), with isolated records from Vietnam, Taiwan and offshore islands (Jenkins et al., 2009).
Distribution in Vietnam. Central and southern Vietnam (Fig. 3B). Jenkins et al. (2009) reported on three museum specimens (kept in the National Museum of Natural History, Smithsonian Institution, Washington, USA) from An Khe, Gia Lai Province and Lang Bian Mt., Lam Dong Province.

Comments. The aforementioned specimens were earlier considered to belong to C. indochinensis (Heaney \& Timm, 1983).

Crocidura sapaensis Jenkins, Abramov, Bannikova, Rozhnov, 2013

Type locality. Vietnam, Lao Cai Province, $\mathrm{Sa} \mathrm{Pa}$ District, c. $6 \mathrm{~km}$ west of $\mathrm{Sa} \mathrm{Pa}$ Town, vicinity of Tram Ton Station of Hoang Lien National Park, north slope of Fan Si Pan Mt. area, elevation 1930-2200 m a.s.l.

Distribution. Known from Vietnam only.

Distribution in Vietnam. Northern Vietnam (Fig. 4B). Based on the cytochrome $b$ analysis and morphology of the third lower molars $\mathrm{m} 3$, the confirmed specimens of $C$. sapaensis have been recorded from Lao Cai Province, $\mathrm{Sa} \mathrm{Pa}$ District. Based on morphology, specimens from the northern part of Lao Cai Province, Ngai Tio (elevation $1450 \mathrm{~m}$ ) and from the vicinity of Cat Cat Village near Sa Pa Town (elevation 1400-1450 m) in relatively close geographical proximity seem to also belong to the same species (Jenkins et al., 2013). 


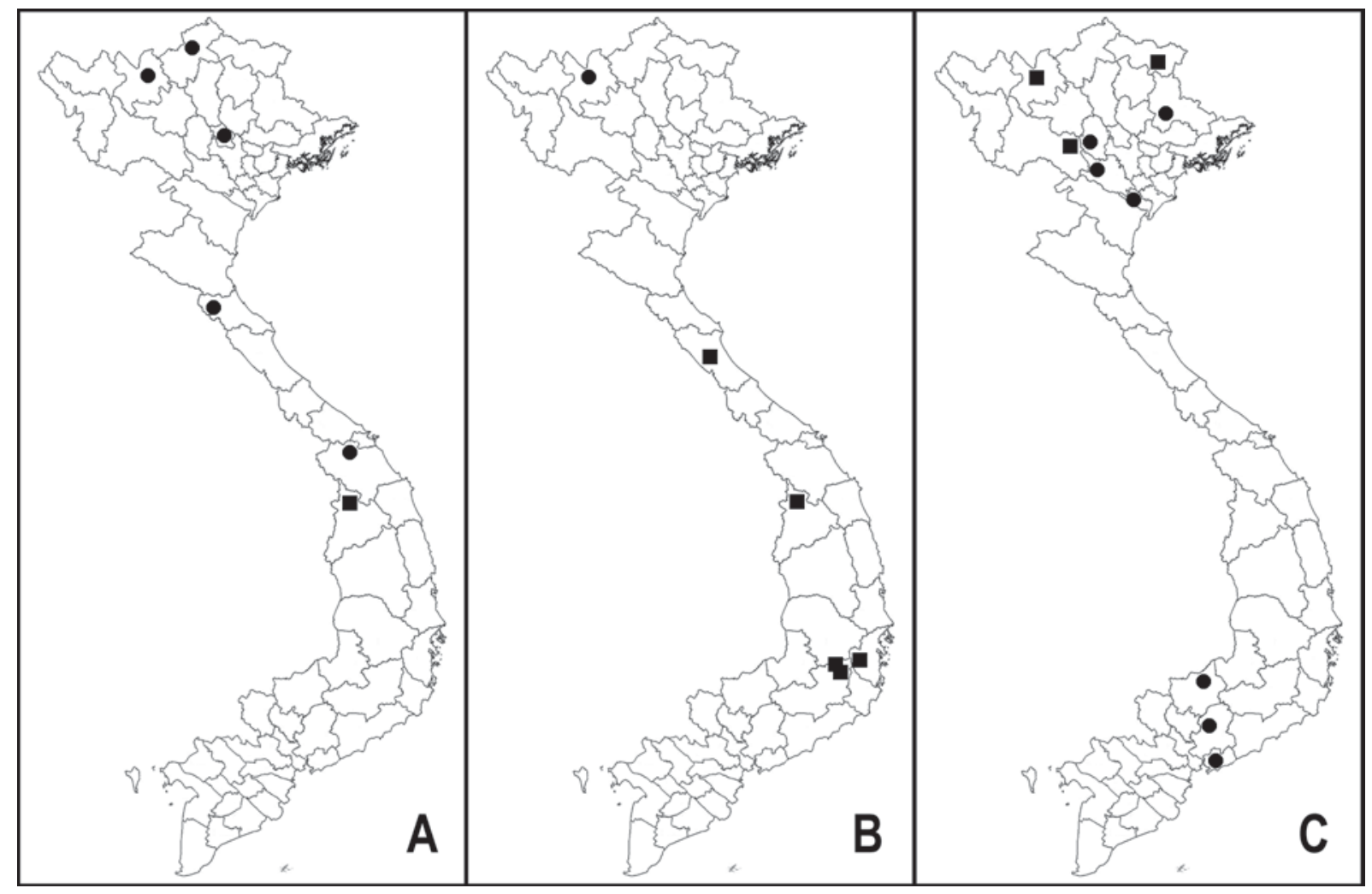

Figure 4. Distribution maps of the Vietnamese insectivores: A - Crocidura wuchihensis (circles), Crocidura sokolovi (squares); B - Crocidura sapaensis (circles), Crocidura zaitsevi (squares); C — Suncus etruscus (circles), Anourosorex squamipes (squares).

Crocidura sokolovi Jenkins, Abramov, Rozhnov, Makarova, 2007

Type locality. Vietnam, Kon Tum Province, west slope of Ngoc Linh Mountain, elevation 2400 m a.s.1.

Distribution. Known from Vietnam only.

Distribution in Vietnam. Central Vietnam (Fig. 4A). Known from the type locality only: at the high elevations of Ngoc Linh Mt., Kon Tum Province (Jenkins et al., 2007; Rozhnov \& Abramov, 2009; Bannikova et al., 2011).

\section{Crocidura tanakae Kuroda, 1938}

Type locality. China, central Taiwan, Taichusiu, Horigai, Shohosha.

Distribution. Central Laos (Khammouane), China (Hunan), Taiwan, Vietnam (Esselstyn et al., 2009; Esselstyn \& Oliveros, 2010; Bannikova et al., 2011).

Distribution in Vietnam. A widespread and common species known throughout Vietnam (Fig. 3C). While C. attenuata in Vietnam appears to occur only to the east of Song Hong (the Red River), in NE Vietnam (Bannikova et al., 2011; Abramov et al., 2012), C. tanakae does not appear to be so restricted and has been recorded on both sides of the river in northern Vietnam and also in central and southern Vietnam (Es- selstyn \& Oliveros, 2010; Bannikova et al., 2011; Jenkins et al., 2013). The genetically confirmed records have been known from Vinh Phuc Province (Tam Dao), Tuyen Quang Province, Ha Tinh Province and Quang Nam Province (Esselstyn \& Oliveros, 2010); Lao Cai Province (Van Ban District), Quang Binh Province (Phong Nha - Ke Bang National Park), Quang Tri Province (Huong Hoa Nature Reserve), Kon Tum Province (Ngoc Linh Mt.), Lam Dong Province (Bi Doup Mt., Hon Giao Mt.), Khanh Hoa Province (Hon Ba Mt.), Binh Phuoc Province (Bu Gia Map Nature Reserve) (Bannikova et al., 2011). The species has recently been found in Ba Vi National Park, Ba Vi District of Hanoi (Abramov et al., 2013).

Comments. An analysis of cytochrome oxidase $c$ subunit I (COI) demonstrated the occurrence of two clearly defined haplogroups of $C$. tanakae within Vietnam: one ( $C$. tanakae A) that occurs in central and southern Vietnam (Huong Hoa, Phong Nha - Ke Bang, Ngoc Linh, Hon Ba, Bi Doup) and another (C. tanakae $\mathrm{B})$ that is restricted to the northern part of the country in Hoang Lien Mountains (Bannikova et al., 2011).

Crocidura wuchihensis Shaw, Wang, Lu, Chang, 1966

Type locality. China, Hainan Island, Shui-Man, western slope of Wuchih Mountain. 
Distribution. China (Hainan Island, western Yunnan), northern Laos, northern Vietnam (Jenkins et al., 2009).

Distribution in Vietnam. Northern and central Vietnam (Fig. 4A). The populations of $C$. wuchihensis identified on the basis of cytochrome $b$ have been found in Mt. Tay Con Linh II, Ha Giang Province (Ohdachi et al., 2006; Esselstyn \& Oliveros, 2010) and from Tam Dao, Vinh Phuc Province (Bannikova et al., 2011; ZIN collection). Based on morphology, the populations that seem to belong to this species also occur in Huong Son, Ha Tinh Province (Lunde et al., 2004; Jenkins et al., 2009), Ba Na, Quang Nam Province (Jenkins et al., 2009) and $\mathrm{Pa}$ Kha and Thai Nien, both in Lao Cai Province (Jenkins et al., 2013).

Comments. Bannikova et al. (2011) suggested that the distribution of $C$. wuchihensis was restricted in Vietnamese territories east and north of the Red River. The population of $C$. wuchihensis recorded from the Annamites (Ha Tinh and Quang Nam provinces) has not been included in any of the previous molecular studies. Based on the multivariate cranial analysis, Jenkins et al. (2009) showed that two groups of C. wuchihensis (from northern and central Vietnam) were moderately well separated from each other. Lacking further evidence from molecular studies, it is impossible to see whether the population from the southern Annamites was correctly assigned to $C$. wuchihensis, or could it belong to $C$. sapaensis or indeed even represent a further undescribed species (see Jenkins et al., 2013).

Crocidura zaitsevi Jenkins, Abramov, Rozhnov, Makarova, 2007

Type locality. Vietnam, Kon Tum Province, west slope of Ngoc Linh Mountain, elevation 2300 m a.s.l.

Distribution. Known from Vietnam only.

Distribution in Vietnam. Central and southern Vietnam (Fig. 4B). In central Vietnam, it has been found in a wide elevation range of Ngoc Linh Mt., Kon Tum Province (Jenkins et al., 2007; Rozhnov \& Abramov, 2009) and in Phong Nha - Ke Bang National Park, Quang Binh Province (Bannikova et al., 2011); also recorded in three localities in southern Vietnam: Bi Doup - Nui Ba National Park, Lam Dong Province, Hon Ba Mt., Khanh Hoa Province (Bannikova et al., 2011), and Chu Yang Sin National Park, Dak Lak Province (ZIN collection).

Comments. The intraspecific differentiation of $C$. zaitsevi is relatively high. Bannikova et al. (2011) found two haplogroups ( $p$-dist $=2.3 \%$, cyt $b$ and $1.5 \%, \mathrm{COI})$ within $C$. zaitsevi, which correspond to central and southern Vietnam localities accordingly: the haplogroup A containing specimens from the type locality (Ngoñ Linh) and the haplogroup B found in southern Vietnam (Hon $\mathrm{Ba}$ and Bi Doup). The haplogroup from the Phong Nha - Ke Bang in central Vietnam is associated with the haplogroup A; however, it is distinct ( $p$-dist $=1.3 \%$, $\mathrm{COI}$ ) and may represent a separate subgroup.
Suncus etruscus (Savi, 1822)

Type locality. Italy, Pisa.

Distribution. Widely distributed across Eurasia (Hutterer, 2005).

Distribution in Vietnam. Sporadically distributed in Vietnam (Fig. 4C), known from four localities in northern part of country: Cuc Phuong National Park, Ninh Binh Province (Feiler \& Nadler, 1997); Huu Lien Nature Reserve, Lang Son Province (Lunde et al., 2007; ZIN collection); Ba Vi National Park, Ba Vi District of Hanoi (Abramov et al., 2013); and Xuan Son National Park, Phu Tho Province (ZIN collection). There are also three localities in southern Vietnam: Ma Da Forest, Vinh Cuu Nature Reserve, Dong Nai Province (Kuznetsov, 2006), Bu Gia Map Nature Reserve, Binh Phuoc Province (Abramov et al., 2009, 2011), and Dinh Mt., Tan Thanh District, Ba Ria - Vung Tau Province (IEBR collection).

\section{Suncus murinus (Linnaeus, 1766)}

Type locality. Indonesia, Java.

Distribution. Widespread throughout the Indomalayan Region, and has been widely introduced in the Philippines, parts of Africa, coastal Arabia, islands in the Indian Ocean and many other regions (Hutterer \& Tranier, 1990; Hutterer, 2005).

Distribution in Vietnam. A widespread, synanthropic species known throughout Vietnam, usually found near human settlements.

\section{Subfamily Soricinae G. Fischer, 1814}

Tribe Anourosoricini Anderson, 1879

Anourosorex squamipes Milne-Edwards, 1872

Type locality. China, Sichuan Province, probably Moupin (= Baoxing).

Distribution. Southern China (Shaanxi, Hubei, Sichuan and Yunnan); northern and western Myanmar, eastern India (Mizoram), northern Vietnam, Thailand (Corbet \& Hill, 1992; Hutterer, 2005)

Distribution in Vietnam. Northern Vietnam (Fig. 4C). It has been collected from a few localities on northern and northwestern slopes of Fan Si Pan Mt., Lao Cai Province (Osgood, 1932; Kuznetsov \& Rozhnov, 1998; Abramov et al., 2008, 2010). Dang Ngoc Can et al. (2008) recorded the species for the Pia Oac locality in Cao Bang Province (IEBR collection). Recently the species has been recorded in Muong Do Nature Reserve, Son La Province (Nguyen Xuan Dang et al., 2012).

Tribe Blarinellini Reumer, 1998

Blarinella griselda Thomas, 1912

Type locality. China, Gansu Province, 42 miles (68 $\mathrm{km})$ southeast of Taochou, elevation 10000 feet (3048 m) a.s.1. 


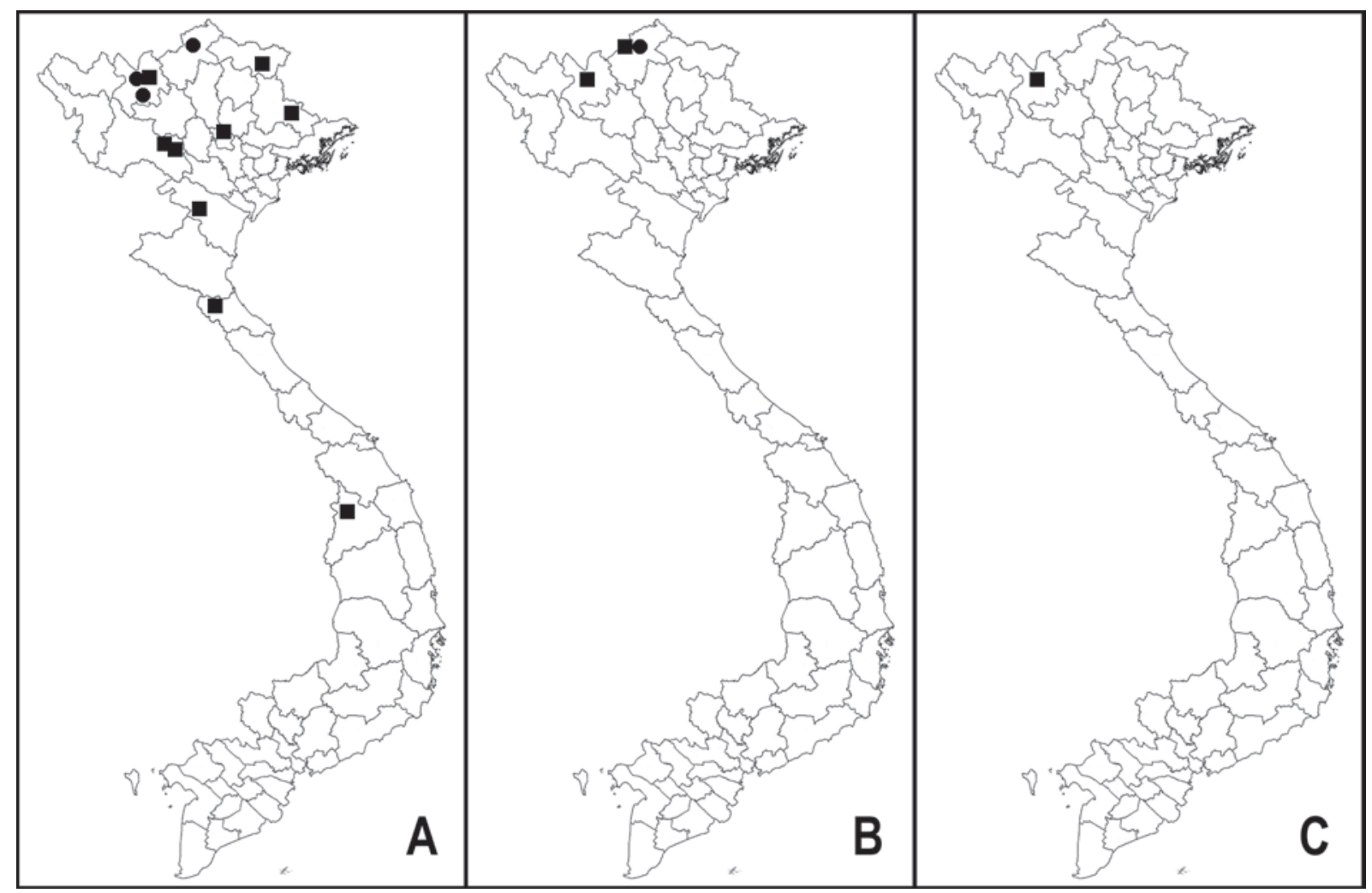

Figure 5. Distribution maps of the Vietnamese insectivores: A - Blarinella griselda (circles), Chimarrogale himalayica (squares); B - Chodsigoa caovansunga (circles), Chodsigoa parca (squares); C - Episoriculus baileyi, Episoriculus caudatus, Episoriculus macrurus, all three species are known from the single locality only (marked by square).

Distribution. China (Gansu, Yunnan and Hubei), northern Vietnam (Hutterer, 2005; Hoffmann \& Lunde, 2008; see also Chen et al., 2012).

Distribution in Vietnam. Northern Vietnam (Fig. 5A). The species was first recorded from Mt. Tay Con Linh II, Ha Giang Province (Lunde et al., 2003). Also it has been found in two localities in Lao Cai Province Van Ban District, Nam Xay Commune and Sa Pa District, near Tram Ton Station (Abramov et al., 2007b).

Tribe Nectogalini Anderson, 1879

Chimarrogale himalayica (Gray, 1842)

Type locality. India, NE Punjab, Chamba (see Corbet \& Hill, 1992: 34).

Distribution. Southeast Asia from Kashmir to Indochina, central and southern China, Taiwan (Hutterer, 2005; Hoffmann \& Lunde, 2008; Lin \& Motokawa, 2010).

Distribution in Vietnam. Only a few records from central and northern Vietnam (Fig. 5A). Osgood (1932) mentioned one specimen from $\mathrm{Sa} \mathrm{Pa}$, Lao Cai Province. From Dak To, Kon Tum Province, Thomas (1927) described a distinct species Chimarrogale varennei which was synonymized with $C$. himalayica (Corbet \& Hill, 1992; Hutterer, 2005). Three specimens were collected from Huong Son District, Ha Tinh Province
(Lunde \& Musser, 2002). Dang Ngoc Can et al. (2008) also listed the Pia Oac locality in Cao Bang Province, Tam Dao National Park in Vinh Phuc Province and Mau Son Mt. in Lang Son Province. Recently the species has been recorded in Muong Do Nature Reserve, Son La Province (Nguyen Xuan Dang et al., 2012), Ta Xua Nature Reserve, Son La Province (ZIN collection) and Xuan Lien Nature Reserve, Thanh Hoa Province (Bui Tuan Hai et al., 2013b).

Comments. Dang Huy Huynh et al. (1994, 2007) referred to varennei as a synonym of Chimarrogale platycephala and listed the latter species in the fauna of Vietnam. Based on the cytochrome $b$ analysis (Yuan et al., 2013), C. himalayica was clearly shown to be as a paraphyletic taxon. Yuan et al. (2013) suggested that three subspecies of $C$. himalayica should be reconsidered as distinct species. They treated the populations from Vietnam and southern China as Chimarrogale varennei. Therefore, additional morphological and molecular analyses are needed to test the taxonomic status of these mitochondrial lineages.

Chodsigoa caovansunga Lunde, Musser, Nguyen Truong Son, 2003

Type locality. Vietnam, Ha Giang Province, Vi Xuyen District, Cao Bo Commune, Mt. Tay Con Linh II, elevation $1500 \mathrm{~m}$ a.s.1. 
Distribution. Northern Vietnam (Lunde et al., 2003) and southern China, Yunnan (He et al., 2012).

Distribution in Vietnam. Northern Vietnam (Fig. 5B). The species has been known from the type locality in Ha Giang Province only (Lunde et al., 2003; IEBR collection).

\section{Chodsigoa parca G. Allen, 1923}

Type locality. China, western Yunnan, Ho-mu-shu Pass, elevation 8000 feet (2438 m) a.s.1.

Distribution. Southwestern China, northern Myanmar, Thailand and Vietnam (Hutterer, 2005).

Distribution in Vietnam. Northern Vietnam (Fig. 5B). The species has been known from two localities only: Sa Pa District, Lao Cai Province (Osgood, 1932; IEBR and ZIN collections) and Mt. Tay Con Linh II, Ha Giang Province (Lunde et al., 2003).

Comments. The specimen from $\mathrm{Sa} \mathrm{Pa}$ was described as a distinct species Chodsigoa lowei (Osgood, 1932). Now this name is considered subspecies and assigned to C. parca (Hoffmann, 1986; Hutterer, 2005).

\section{Episoriculus baileyi (Thomas, 1914)}

Type locality. India, Arunachal Pradesh, Mishmi Hills, Tsu River, elevation 7500 feet (2286 m) a.s.1.

Distribution. India (Sikkim, Assam), southern China (Sichuan, Yunnan, Xizang), northern Myanmar, northern Vietnam (Hutterer, 2005; Hoffmann \& Lunde, 2008; Motokawa \& Lin, 2005; see comments below).

Distribution in Vietnam. Northern Vietnam (Fig. 5C). The species has been known from the vicinity of Fan Si Pan Mt., Sa Pa District, Lao Cai Province only (Osgood, 1932; Kuznetsov \& Rozhnov, 1998; ZMMU collection).

Comments. Many authors have placed baileyi in $E$. leucops as a subspecies or even a synonym (Hoffmann, 1986; Corbet \& Hill, 1992; Motokawa, 2003; Hutterer, 2005; Hoffmann \& Lunde, 2008; Dang Ngoc Can et al., 2008). However, Motokawa \& Lin (2005) revised a species composition of Soriculus sensu lato on the basis of external and cranial morphological characteristics and proved Episoriculus baileyi to be a valid species. According to Motokawa \& Lin (2005), the distribution range of $E$. leucops is restricted to Nepal, whereas that of E. baileyi lies in northeastern India, China, northern Myanmar and northern Vietnam.

\section{Episoriculus caudatus (Horsfield, 1851)}

Type locality. India, "Sikim and Darjeling". Ellerman \& Morrison-Scott (1951: 59) restricted it to the type locality to "Darjeeling".

Distribution. Northern India (Sikkim, Uttarakhand and West Bengal) and Nepal (Molur et al., 2005), central and southern China (Xizang, Sichuan, Gansu and southwestern Yunnan), northern Myanmar (Hoffmann \& Lunde, 2008), northern Vietnam.
Distribution in Vietnam. Northern Vietnam (Fig. 5C). The species has been known from Sa Pa District, Lao Cai Province only (Dang Ngoc Can et al., 2008; ZIN collection).

Comments. The species is morphologically close to Episoriculus macrurus but its tail is shorter (Hoffmann, 1986). According to the same author (Op. cit.: 467-468), "it occurs from Kashmir eastward to western and southern China, and northern Burma, but not, apparently, Vietnam". Many previous authors listed $E$. caudatus in the fauna of Vietnam on the basis of the erroneous synonymization of baileyi and caudatus (Ellerman \& Morrison-Scott, 1951; Dang Huy Huynh et al., 1994, 2007; Kuznetsov, 2006). The specimen ZIN 99787 from $\mathrm{Sa} \mathrm{Pa}$ District seems to be the only known museum specimen of E. caudatus from Vietnam.

\section{Episoriculus macrurus (Blanford, 1888)}

Type locality. India, Darjeeling.

Distribution. Central Nepal to Sikkim, India, western and southern China (Yunnan, Sichuan), northern Myanmar and northern Vietnam (Corbet \& Hill, 1992; Hutterer, 2005; Hoffmann \& Lunde, 2008).

Distribution in Vietnam. Northern Vietnam (Fig. 5C). The species has been known from $\mathrm{Sa} \mathrm{Pa}$ District, Lao Cai Province only (Osgood, 1932; see also Kuznetsov, 2006).

Comments. The species has been reported from Vietnam (Corbet \& Hill, 1992; Hutterer, 2005; Kuznetsov, 2006; Hoffmann \& Lunde, 2008) on the basis of the single specimen (No.39030, Field Museum, Chicago, USA) from "Mount Fan Si Pan (alt. 10000 feet), near Chapa" studied by Osgood (1932). Osgood (1932: 250) placed macrurus as a synonym of leucops and this opinion has been followed by the subsequent authors (see Hoffmann, 1986).

\section{Conclusions}

The fauna of insectivorous mammals of Vietnam is very rich and includes 32 species from 12 genera and three families. Many species still remain known from the territory of Vietnam only: at least, seven species of the white-toothed shrews (Crocidura annamitensis, $C$. guy, C. kegoensis, C. phuquocensis, C. sapaensis, $C$. sokolovi, C. zaitsevi) and a mole species (Euroscaptor subanura). The distributional range of Crocidura indochinensis, which was considered a widespread species in SE Asia, seems to be restricted to southern Vietnam only. The red-toothed shrew Chodsigoa caovansunga described as an endemic species of Vietnam has recently been found in a single locality of southern China (He et al., 2012). Some species (Crocidura rapax, Episoriculus macrurus) remain poorly-known and their occurrence in Vietnam is still questionable.

The values for species richness and endemism given here will necessarily change, as soon as new species are discovered both in the wild and in museum collections 
Table. Species composition of the insectivorous mammals of Vietnam according to recent checklists.

\begin{tabular}{|c|c|c|c|c|}
\hline Family & $\begin{array}{c}\text { Dang Huy Huynh et al., } \\
1994\end{array}$ & $\begin{array}{c}\text { Kuznetsov, } \\
2006\end{array}$ & $\begin{array}{c}\text { Dang Ngoc Can et al., } \\
2008\end{array}$ & This study \\
\hline \multirow{2}{*}{$\begin{array}{l}\text { Erinacei- } \\
\text { dae }\end{array}$} & Hylomys suillus & Hylomys suillus & Hylomys suillus & Hylomys suillus \\
\hline & Neotetracus sinensis & Hylomys sinensis & Neotetracus sinensis & Neotetracus sinensis \\
\hline \multirow{3}{*}{ Talpidae } & & & Scaptonyx fusicaudus & Scaptonyx fusicaudus \\
\hline & $\begin{array}{l}\text { Parascaptor klossi } \\
\text { Parascaptor leucura }\end{array}$ & $\begin{array}{l}\text { Talpa longirostris } \\
\text { Talpa micrura }\end{array}$ & $\begin{array}{l}\text { Euroscaptor longirostris } \\
\text { Euroscaptor parvidens }\end{array}$ & $\begin{array}{l}\text { Euroscaptor } \\
\text { longirostris } \\
\text { Euroscaptor parvidens } \\
\text { Euroscaptor subanura }\end{array}$ \\
\hline & & & Mogera latouchei & Mogera latouchei \\
\hline \multirow{8}{*}{ Soricidae } & $\begin{array}{l}\text { Crocidura attenuata } \\
\text { Crocidura dracula } \\
\text { Crocidura horsfieldi }\end{array}$ & $\begin{array}{l}\text { Crocidura attenuata } \\
\text { Crocidura fuliginosa } \\
\text { Crocidura horsfieldi }\end{array}$ & $\begin{array}{l}\text { Crocidura attenuata } \\
\text { Crocidura fuliginosa } \\
\text { Crocidura indochinensis } \\
\text { Crocidura kegoensis } \\
\text { Crocidura sokolovi } \\
\text { Crocidura wuchihensis } \\
\text { Crocidura zaitsevi }\end{array}$ & $\begin{array}{l}\text { Crocidura annamitensis } \\
\text { Crocidura attenuata } \\
\text { Crocidura dracula } \\
\text { Crocidura fuliginosa } \\
\text { Crocidura guy } \\
\text { Crocidura } \\
\text { indochinensis } \\
\text { Crocidura kegoensis } \\
\text { Crocidura phanluongi } \\
\text { Crocidura } \\
\text { phuquocensis } \\
\text { Crocidura rapax } \\
\text { Crocidura sapaensis } \\
\text { Crocidura sokolovi } \\
\text { Crocidura tanakae } \\
\text { Crocidura wuchihensis } \\
\text { Crocidura zaitsevi }\end{array}$ \\
\hline & Suncus murinus & $\begin{array}{l}\text { Suncus etruscus } \\
\text { Suncus murinus }\end{array}$ & $\begin{array}{l}\text { Suncus etruscus } \\
\text { Suncus murinus }\end{array}$ & $\begin{array}{l}\text { Suncus etruscus } \\
\text { Suncus murinus }\end{array}$ \\
\hline & Anourosorex squamipes & Anourosorex squamipes & Anourosorex squamipes & Anourosorex squamipes \\
\hline & & & Blarinella griselda & Blarinella griselda \\
\hline & $\begin{array}{l}\text { Chimarrogale himalayica } \\
\text { Chimarrogale } \\
\text { platycephala }\end{array}$ & $\begin{array}{l}\text { Chimarrogale } \\
\text { himalayica }\end{array}$ & Chimarrogale himalayica & $\begin{array}{l}\text { Chimarrogale } \\
\text { himalayica }\end{array}$ \\
\hline & & & $\begin{array}{l}\text { Chodsigoa caovansunga } \\
\text { Chodsigoa parca }\end{array}$ & $\begin{array}{l}\text { Chodsigoa } \\
\text { caovansunga } \\
\text { Chodsigoa parca }\end{array}$ \\
\hline & $\begin{array}{l}\text { Soriculus caudatus } \\
\text { Soriculus leucops } \\
\text { Soriculus lowei }\end{array}$ & $\begin{array}{l}\text { Soriculus caudatus } \\
\text { Soriculus leucops } \\
\text { Soriculus macrurus } \\
\text { Soriculus parca } \\
\end{array}$ & $\begin{array}{l}\text { Soriculus caudatus } \\
\text { Soriculus leucops }\end{array}$ & \\
\hline & & & & $\begin{array}{l}\text { Episoriculus baileyi } \\
\text { Episoriculus caudatus } \\
\text { Episoriculus macrurus }\end{array}$ \\
\hline
\end{tabular}

and the ranges of known species are clarified (Sterling et al., 2006). New findings and taxonomic studies of insectivorous mammals have changed the species composition of Vietnam fauna significantly (see Table).

The detailed geographical distribution, ecology, and natural history of the majority of insectivorous mammals of Vietnam are still poorly studied. Morphological characters and genetic variation in the populations of the widespread species such as Suncus etruscus,
Crocidura tanakae, Crocidura phanluongi, Euroscaptor parvidens and some others need to be examined in detail. Undoubtedly, the number of lipotyphlan species in Vietnam and Southeast Asia will increase, should targeted insectivorous mammals surveys are undertaken there.

ACKNOWLEDGEMENTS. We thank Dr. Nguyen Duc Anh (IEBR, Vietnam) for the help with prepara- 
tion of maps, Mrs. Nguyen Vu Khoi (Wildlife at Risk, Vietnam), Phung My Trung (Dong Nai Custom, Dong Nai Province, Vietnam), Dr. Le Manh Hung (IEBR, Vietnam) and Mr. Nguyen Thien Tao (VNMN, Vietnam) for providing us with the specimens from the IEBR collection. We thank Mr. A.V. Shchinov (Joint Vietnam-Russian Tropical Research and Technological Centre) for his great help during the field work. We are obliged to Dr. D.V. Logunov (Manchester Museum, UK) for linguistic help and are grateful to two anonymous referees for their critical comments on the ms. This research was supported in part by the joint grant No.12-04-93005 from Russian Foundation for Basic Research and Vietnamese Academy of Science and Technology, and funded by Vietnam National Foundation for Science and Technology Development (NAFOSTED) under the grant No. 106.12-2011.06.

\section{References}

Abramov A.V. \& Kruskop S.V. 2012. The mammal fauna of Cat Ba Island, northern Vietnam // Russian Journal of Theriology. Vol.11. No.1. P.57-72.

Abramov A.V., Bannikova A.A. \& Rozhnov V.V. 2012. White-toothed shrews (Mammalia, Soricomorpha, Crocidura) of coastal islands of Vietnam // Zookeys. No.207. P. 37-47.

Abramov A.V., Jenkins P.D., Rozhnov V.V. \& Kalinin A.A. 2008. Description of a new species of Crocidura (Soricomorpha: Soricidae) from the island of Phu Quoc, Vietnam // Mammalia. Vol.72. No.4. P.269-272.

Abramov A.V., Kruskop S.V. \& Shchinov A.V. 2010a. Small mammals of the Dalat Plateau, southern Vietnam // Russian Journal of Theriology. Vol.8 (for 2009). No.2. P.6173.

Abramov A.V., Rozhnov V.V. \& Morozov P.N. 2007a. Notes on mammals of the Ngoc Linh Nature Reserve (Vietnam, Kon Tum Province) // Russian Journal of Theriology. Vol.5. No.2. P.85-92.

Abramov A.V., Rozhnov V.V., Shchinov A.V. \& Makarova O.V. 2007b. New records of the Asiatic short-tailed shrew Blarinella griselda (Soricidae) from Vietnam // Mammalia. Vol.71. No.4. P.181-182.

Abramov A.V., Rozhnov V.V., Shchinov A.V. \& Nguyen Truong Son. 2009. Distribution of rare and lesser-known insectivores (Soricomorpha) in Vietnam // Proceedings of the $3^{\text {rd }}$ National Scientific Conference on Ecology and Biological Resources. Hanoi: Institute of Ecology and Biological Resources. P.9-11.

Abramov A.V., Shchinov A.V. \& Balakirev A.E. 2011. Contributions to the study of small non-volant mammal fauna in Bu Gia Map National Park (Binh Phuoc Province) $/ /$ Proceedings of the $4^{\text {th }}$ National Scientific Conference on Ecology and Biological Resources. Hanoi: Institute of Ecology and Biological Resources. P.20-25.

Abramov A.V., Shchinov A.V. \& Rozhnov V.V. 2008. Study of insectivorous mammals in North Vietnam // Contemporary Problems of Ecology. Vol.1. No.5. P.593-595.

Abramov A.V., Shchinov A.V. \& Rozhnov V.V. 2010 b. Soricidae of Sa Pa Area (Northern Vietnam) // Rozhnov
V.V. (ed.). Advances in the Biology of Shrews - III. Moscow: KMK Scientific Press. P.5.

Abramov A.V., Shchinov A.V. \& Tran Quang Tien. Insectivorous mammals (Mammalia: Eulipotyphla) of the Ba Vi National Park, Northern Vietnam // Proceedings of the Zoological Institute RAS. Vol.317. No.3. P.221225.

Bannikova A.A. \& Lebedev V.S. 2012. Order Eulipotyphla // Pavlinov I.Ya. \& Lissovsky A.A. (eds.). The Mammals of Russia: A Taxonomic and Geographic Reference (Archives of the Zoological Museum of Moscow State University). Moscow: KMK Scientific Press. P.25-72.

Bannikova A.A., Abramov A.V., Borisenko À.V., Lebedev V.S. \& Rozhnov V.V. 2011. Mitochondrial diversity of the white-toothed shrews (Mammalia, Eulipotyphla, Crocidura) in Vietnam // Zootaxa. No.2812. P.1-20.

Blyth E. 1855. Report for May Meeting, 1855 // Journal of the Asiatic Society of Bengal. Vol.24. No.4. P.359-363.

Bui Tuan Hai, Nguyen Truong Son \& Dang Ngoc Can. 2013a. Supplement the data of species distribution of genus Crocidura (Mammalia, Soricomorpha) in Vietnam // Program and Abstracts of Third International Symposium on East Asian Vertebrate Species Diversity. Hanoi, September 2013. Hanoi: Institute of Ecology and Biological Resources. P.49.

Bui Tuan Hai, Nguyen Truong Son \& Motokawa M. 2013b. Water shrew catching // Program and Abstracts of Third International Symposium on East Asian Vertebrate Species Diversity. Hanoi, September 2013. Hanoi: Institute of Ecology and Biological Resources. P.22.

Cao Van Sung. 1976. New data on morphology and biology of some rare small mammals from North Vietnam // Zoologicheskii Zhurnal. T.55. No.12. P.1880-1885 [in Russian with English summary].

Chen S., Liu S., Liu Y., He K., Chen W., Zhang X., Fan Z., Tu F., Jia X. \& Yue B. 2012. Molecular phylogeny of Asiatic short-tailed shrews, genus Blarinella Thomas, 1911 (Mammalia: Soricomorpha: Soricidae) and its taxonomic implications // Zootaxa. No.3250. P.43-53.

Chiozza F. 2008. Euroscaptor parvidens // IUCN 2011. IUCN Red List of Threatened Species. Version 2011.2. $<$ www.iucnredlist.org $>$. Downloaded on 01 February 2013.

Corbet G.B. \& Hill J.E. 1992. The Mammals of the Indomalayan Region: a Systematic Review. Oxford: Oxford University Press. 488 p.

Dang Huy Huynh, Dao Van Tien, Cao Van Sung, Pham Trong Anh \& Hoang Minh Khien. 1994. [Checklist of Mammals in Vietnam]. Hanoi: Publishing House "Science and Technics". 168 p. [in Vietnamese].

Dang Huy Huynh, Hoang Minh Khien, Le Xuan Canh, Nguyen Xuan Dang, Vu Dinh Thong \& Dang Huy Phuong. 2007. [Mammals of Vietnam. Morphology, Biology and Ecology of Some Species]. Vol.1. Hanoi: Science and Technics Publishing House. 232 p. [in Vietnamese].

Dang Ngoc Can, Endo H., Nguyen Truong Son, Oshida T., Le Xuan Canh, Dang Huy Phuong, Lunde D.P., Kawada S.-I., Hayashida A. \& Sasaki M. 2008. Checklist of Wild Mammal Species of Vietnam. Hanoi: Primate Research Institute, Inuyama, Japan \& Institute of Ecology and Biological Resources. 400 p. [in Vietnamese]. 
Dang Ngoc Can, Nguyen Truong Son, Kawada S.-I. \& Motokawa M. 2013. Status and distribution of moles (Soricomorpha, Talpidae) in Vietnam // in press.

Dao Van Tien. 1966. Notes sur une collection de petits mammiferes des regions de Thanh-hoa, Nghe-an, Hatinh et Quang-binh (Centre Vietnam) // Zoologischer Anzeiger. Bd.176. H.6. S.428-437.

Esselstyn J.A. \& Oliveros C.H. 2010. Colonization of the Philippines from Taiwan: a multi-locus test of the biogeographic and phylogenetic relationships of isolated populations of shrews // Journal of Biogeography. Vol.37. P.1504-1514.

Esselstyn J.A., Timm R.M. \& Brown R.M. 2009. Do geological or climatic processes drive speciation in dynamic archipelagos? The tempo and mode of diversification in Southeast Asian shrews // Evolution. Vol.63. P.25952610.

Feiler A. \& Nadler T. 1997. Erstnachweis der Etruskerspitzmaus, Suncus etruscus (Savi, 1822), für Vietnam (Mammalia: Insectivora: Soricidae) // Faunistische Abhandlungen, Staatliches Museum für Tierkunde, Dresden. Vol.21. P.161-162.

Feiler A., Nadler T. \& Stefen C. 2008. Bemerkungen zu Kleinsäugern der vietnamesischen Nationalparke Cuc Phuong und Phong Nha-Ke Bang und des Naturschutzgebietes Ke Go // Vertebrate Zoology. Vol.58. No.1. P.113125

He K., Deng K. \& Jiang X.-L. 2012. First record of Van Sung's shrew (Chodsigoa caovansunga) in China // Zoological Research. Vol.33. No.5. P.542-544 [in Chinese with English abstract].

Heaney L.R. \& Timm R.M. 1983. Systematics and distribution of shrews of the genus Crocidura (Mammalia: Insectivora) in Vietnam // Proceedings of the Biological Society of Washington. Vol.96. P.115-120.

Hoffmann R.S. 1986. A review of the genus Soriculus (Mammalia: Insectivora) // Journal of the Bombay Natural History Society. Vol.82. No.3. P.459-481.

Hoffmann R.S. \& Lunde D. 2008. Order Erinaceomorpha, Order Soricomorpha // Smith A.T. \& Xie Y. (eds.). A Guide to the Mammals of China. Princeton: Princeton University Press. P.292-327.

Hutterer R. 2005. Order Erinaceomorpha, Order Soricomorpha // Wilson D.E. \& Reeder D.M. (eds.). Mammals Species of the World. A Taxonomic and Geographic Reference. Third edition. Baltimore: The Johns Hopkins University Press. P.212-311.

Hutterer R. \& Tranier M. 1990. The immigration of the Asian house shrew Suncus murinus into Africa and Madagascar // Peters G. \& Hutterer R. (eds.). Vertebrates in the Tropics. Bonn: Museum Alexander Koenig. P.309-319.

Jenkins P.D., Abramov A.V., Rozhnov V.V. \& Makarova O.V. 2007. Description of two new species of whitetoothed shrews belonging to the genus Crocidura (Soricomorpha: Soricidae) from the Ngoc Linh Mountain, Vietnam // Zootaxa. No.1589. P.57-68.

Jenkins P.D., Abramov A.V., Rozhnov V.V. \& Olsson A. 2010. A new species of Crocidura (Soricomorpha: Soricidae) from southern Vietnam and north-eastern Cambodia // Zootaxa. No.2345. P.60-68.
Jenkins P.D., Abramov A.V., Bannikova A.A. \& Rozhnov V.V. 2013. Bones and genes: resolution problems in three Vietnamese species of Crocidura (Mammalia, Soricomorpha, Soricidae) and the description of an additional new species // Zookeys. No.313. P.61-79.

Jenkins P.D., Lunde D.P. \& Moncrieff C.B. 2009. Chapter 10. Descriptions of new species of Crocidura (Soricomorpha: Soricidae) from mainland Southeast Asia, with synopses of previously described species and remarks on biogeography // Voss R.S. \& Carleton M.C. (eds.). Systematic Mammalogy: Contributions in Honour of Guy G. Musser. Bulletin of the American Museum of Natural History. Vol.331 P.356-405.

Kawada S.-I., Nguyen Truong Son \& Dang Ngoc Can. 2008. Karyological diversity of talpids from Vietnam (Insectivora, Talpidae) // Dang Ngoc Can et al. Checklist of Wild Mammal Species of Vietnam. Hanoi: Primate Research Institute, Inuyama, Japan \& Institute of Ecology and Biological Resources. P.384-389.

Kawada S.-I., Nguyen Truong Son \& Dang Ngoc Can. 2009. Moles (Insectivora, Talpidae, Talpinae) of Vietnam // Bulletin of the National Museum of Nature and Science. Vol.35. No.2. P.89-101.

Kawada S.-I., Nguyen Truong Son \& Dang Ngoc Can. 2012. A new species of mole of the genus Euroscaptor (Soricomorpha, Talpidae) from northern Vietnam // Journal of Mammalogy. Vol.93. No.3. P.839-850.

Kuznetsov G.V. 2006. [Mammals of Vietnam]. Moskva: KMK Scientific Press. 428 p. [in Russian].

Kuznetsov G.V. \& Rozhnov V.V. 1998. [Mammals of the mountain region of Sa Pa and Fan Si Pan: biodiversity and problems of their conservation] // Korzun L.P. \& Kalyakin M.V. (eds.). [Materials of Zoological and Botanical Studies in the Fan Si Pan Summit Area (North Vietnam)]. Moskva-Khanoi: Tropical Centre. P.129-158 [in Russian with English summary].

Le Trong Trai, Richardson W.J., Bui Dac Tuyen, Le Van Cham, Nguyen Huy Dung, Ha Van Hoach, Monastyrskii A.L. \& Eames J.C. 1999. An Investment Plan for Ngoc Linh Nature Reserve, Kon Tum Province, Vietnam: a Contribution to the Management Plan. Hanoi: BirdLife International Vietnam Programme. $106 \mathrm{p}$.

Lin L.-K. \& Motokawa M. 2010. Mammals of Taiwan. Vol.1. Soricomorpha. 89 p. http://mammal.biota.biodiv.tw/.

Lunde D.P. \& Musser G.G. 2002. The capture of the Himalayan water shrew (Chimarrogale himalayica) in Vietnam // Mammal Study. Vol.27. No.2. P.137-140.

Lunde D.P., Musser G.G. \& Nguyen Truong Son. 2003. A survey of small mammals from Mt Tay Con Linh II, Vietnam, with the description of a new species of Chodsigoa (Insectivora: Soricidae) // Mammal Study. Vol.28. P.31-46.

Lunde D.P., Musser G.G. \& Ziegler T. 2004. Description of a new species of Crocidura (Soricomorpha: Soricidae, Crocidurinae) from Ke Go Nature Reserve, Vietnam // Mammal Study. Vol.29. P.27-36.

Lunde D.P., Nguyen Truong Son \& Musser G.G. 2007. A survey of small mammals from Huu Lien Nature Reserve, Lang Son Province, Vietnam // Mammal Study. Vol.32. P.155-168. 
Miller G.S. 1940. A new mole from Annam // Journal of Mammalogy. Vol.21. No.2. P.203-204.

Molur S., Srinivasulu C., Srinivasulu B., Walker S., Nameer P.O. \& Ravikumar L. 2005. Status of South Asian NonVolant Small Mammals: Conservation Assessment and Management Plan (C.A.M.P.) Workshop Report. Coimbatore, India: Zoo Outreach Organisation / CBSG-South Asia. 618 p.

Motokawa M. 2003. Soriculus minor Dobson, 1890, senior synonym of $S$. radulus Thomas, 1922 (Insectivora, Soricidae) // Mammalian Biology. Vol.68. P.178-180.

Motokawa M. 2004. Phylogenetic relationships within the family Talpidae (Mammalia: Insectivora) // Journal of Zoology. Vol.263. No.2. P.147-157.

Motokawa M. \& Lin L.-K. 2005. Taxonomic status of Soriculus baileyi (Insectivora, Soricidae) // Mammal Study. Vol.30. P.117-124.

Nguyen Xuan Dang, Nguyen Xuan Nghia, Nguyen Truong Son \& Tran Hong Hai. 2012. Study of mammal diversity in Xuan Nha and Muong Do Nature Reserves, Son La Province, northwestern Vietnam // Mammal Study. Vol.37. No.1. P.55-62.

Ohdachi S.D., Hasegawa M., Iwasa M.A., Vogel P., Oshida T., Lin L.-K. \& Abe H. 2006. Molecular phylogenetics of soricid shrews (Mammalia) based on mitochondrial cytochrome $b$ gene sequences: with special reference to the Soricinae // Journal of Zoology. Vol.270. No.1. P.177191.

Osgood W.H. 1932. Mammals of the Kelley-Roosevelts and Delacour Asiatic expeditions // Field Museum of Natural History. Publication No.132. Zoology Series. Vol.18. No.10. P.193-339.

Pavlinov I.Ya. 2003. [Taxonomy of Recent Mammals] // Archives of Zoological Museum of Moscow State University. T.46. P.3-297 [in Russian].

Pham Nhat, Nguyen Xuan Dang \& Polet G. 2001. Field Guide to the Key Mammal Species of Cat Tien National Park. Hanoi: WWF Cat Tien National Park Conservation Project and Fauna and Flora International - Indochina Programme. $145 \mathrm{p}$.

Robinson H.C. \& Kloss C.B. 1922. New mammals from French Indo-China and Siam // Annals and Magazine of Natural History. Ser.9. Vol.9. P.87-99.
Rozhnov V.V. \& Abramov A.V. 2009. [Insectivorous mammals of Ngoc Linh Mt., Vietnam] // Rozhnov V.V. et al. (eds.). [Fauna of Mountainous Territories]. Moskva: KMK Scientific Press. P.455-459 [in Russian].

Shinohara A., Kawada S.-I., Nguyen Truong Son, Dang Ngoc Can \& Koshimoto C. 2013. Phylogenetic position and intra-species diversity of newly described mole, $E u$ roscaptor subanura Kawada et al., 2012, found from Northern Vietnam // Program and Abstracts of Third International Symposium on East Asian Vertebrate Species Diversity. Hanoi, September 2013. Hanoi: Institute of Ecology and Biological Resources. P.48.

Sterling E.J., Hurley M.M. \& Le Duc Minh. 2006. Vietnam: A Natural History. New Haven \& London: Yale University Press. 423 p.

Stroganov S.U. 1948. [Systematics of the moles (Talpidae)] // Trudy Zoologicheskogo Instituta AN SSSR. T.8. Vyp.2. P.289-406 [in Russian].

Thomas O. 1925. The mammals obtained by Mr. Herbert Stevens on the Sladen-Godman expedition to Tonkin // Proceedings of the Zoological Society of London. Vol.95. No.2. P.495-506

Thomas O. 1927. The Delacour exploration of French IndoChina - Mammals // Proceedings of the Zoological Society of London. Vol.97. No.1. P.41-58.

Van Peenen P.F.D., Cunningham M.L. \& Duncan J.F. 1970. A collection of mammals from Con Son Island, Vietnam // Journal of Mammalogy. Vol.51. P.419-424.

Wang Y.X. 2003. A Complete Checklist of Mammal Species in China. A Taxonomic and Geographic Reference. Beijing: China Forestry Publishing House. 394 p.

Zemlemerova E.D., Bannikova A.A., Abramov A.V., Lebedev V.S. \& Rozhnov V.V. 2013. New data on molecular phylogeny of the East Asian moles // Doklady Biological Sciences. Vol.451. No.1. P.257-260.

Yuan S.-L., Jiang X.-L., Li Z.-J., He K., Harada M., Oshida T. \& Lin L.-K. 2013. A mitochondrial phylogeny and biogeographical scenario for Asiatic water shrews of the genus Chimarrogale: implications for taxonomy and lowlatitude migration routes // PLoS ONE. 8(10): e77156. 